\title{
Elevated serum alpha-I-antitrypsin concentration is associated with HIV disease non-progression
}

\begin{abstract}
Association between reduced serum alpha-1 antitrypsin ( $\alpha 1 \mathrm{AT})$ concentration and HIV infection has been reported. The possible role of $\alpha 1 \mathrm{AT}$ in a subset of people living with HIV who achieved control over HIV-1 disease progression without treatment has not been substantiated. We thus hypothesized that increased serum concentrations of $\alpha 1 \mathrm{AT}$ would be associated with control of HIV disease progression in the absence of highly antiretroviral therapy (HAART). We compared serum concentrations of $\alpha 1 \mathrm{AT}$ in a cross-section of HIV1-infected subjects naïve to HAART and yet resist progression to AIDS (HAART-) with those in whom control of disease progression was achieved by HAART (HAART + ). Mean $\alpha 1 \mathrm{AT}$ concentration was significantly higher in the HAART-group $(177 \pm 17 \mathrm{mg} / 100 \mathrm{~mL})$ compared with HAART $+(126 \pm 12 \mathrm{mg} / 100 \mathrm{~mL} ; \mathrm{p}=0.018)$. Serum $\alpha 1 \mathrm{AT}$ concentrations less than $100 \mathrm{mg} / 100 \mathrm{~mL}$ were found in $14 \%$ and $41 \%$ in HAART- and HAART + group, respectively. Serum $\alpha 1$ ATconcentration and blood CD4+ T cells count in the HAARTgroup were positive correlated $(\mathrm{R}=0.426 ; \mathrm{p}=0.021)$. Increased expression of $\alpha 1 \mathrm{AT}$ may contribute to effective control of HIV disease progression in the absence of HAART. Our findings support the possible use of alpha-1-antitrypsin in HIV disease management.
\end{abstract}

Volume 2 Issue 3 - 2015

\author{
Adebayo L Adedeji, ${ }^{1,2}$ Theophilus L Olawoye ${ }^{2}$ \\ 'Department of Biochemistry, Ladoke Akintola University of \\ Technology, Nigeria \\ ${ }^{2}$ Department of Biochemistry, Federal University of Technology, \\ Nigeria
}

Correspondence: Olawoye TL, Department of Biochemistry, Federal University of Technology, PMB 704,Akure, Nigeria, Tel +234(0)803360I 166, Email tlolawoye@yahoo.co.uk

Received: August 0I, 2015 | Published: August 18, 2015

Keywords: alpha-1-antitrypsin, HIV disease non-progression

\section{Introduction}

Alpha 1-antitrypsin ( $\alpha 1 \mathrm{AT})$ is a glycoprotein, synthesized majorly in the liver and to lesser degree in extra-hepatic tissues. ${ }^{1}$ In normal adult populations, the $95 \%$ reference range in blood is $100-270$ $\mathrm{mg} / 100 \mathrm{ml} .2$ Its serum concentration can raise many folds during acute inflammation. ${ }^{3}$ The main physiological function of $\alpha 1 \mathrm{AT}$ is inactivation of potentially harmful proteinase, notably neutrophil elastase. ${ }^{4,5}$ The interaction between a typical proteinase and $\alpha 1 \mathrm{AT}$ is non-covalent. The bound complex renders the proteinase and $\alpha 1 \mathrm{AT}$ inactive. While the neutrophil elastase is completely inactive in the presence of $\alpha 1 \mathrm{AT}$, the cleaved peptide of $\alpha 1 \mathrm{AT}$ is still immunologically active. The cleaved peptide has been demonstrated to have neutrophil chemo-attractant properties. ${ }^{6}$ This phenomenon emphasizes the importance of $\alpha 1 \mathrm{AT}$ in inflammatory reactions.

Furthermore, there are evidences that $\alpha 1 \mathrm{AT}$ exerts antimicrobial activities. Knappstein et al. ${ }^{7}$ reported that $\alpha 1$ AT binds to the secreted enteropathogenic E. coli proteins and strongly reduces their mediated haemolysis of red blood cells. Bilello et al. ${ }^{8}$ also showed that $\alpha 1$ AT possesses anti HIV activities in vitro. Since $\alpha 1 \mathrm{AT}$ neutralizes other proteases, the functions of proteases required for HIV-1 propagation may also be inhibited. Functional levels of $\alpha 1$ AT may therefore be associated with control of HIV disease progression. Although, association between reduced serum $\alpha 1$ ATconcentration and HIV infection has been shown to be consistent with a role for $\alpha 1$ ATas an endogenous HIV suppressor, ${ }^{9-11}$ it is not very clear whether $\alpha 1$ ATplays significant role in subsets of people living with HIV who achieved control over HIV-1 disease progression without treatment. We thus hypothesized that increased serum concentrations of $\alpha 1$ ATwould be associated patients who exhibit natural control of HIV disease progression in the absence of highly active antiretroviral therapy (HAART-). In the present study, we compared serum concentrations of $\alpha 1$ ATin subset of HIV-1-infected subjects naïve treatment and yet resist progression to AIDS with subjects whose control of disease progression was achieved by HAART as this may reveal the possible use of $\alpha 1$ AT in the management of HIV disease.

\section{Materials and methods}

\section{Selection of subjects}

A cross-section of sixty-eight HIV-1-infected subjects attending Living Hope Care (LIHOC), Ilesa, Nigeria was studied. LIHOC is a Non-Governmental Organization, providing care for people living with HIV/AIDS. Status and demographic characteristics and antiretroviral therapy records was collected. Thirty-three of subjects had been receiving effective HAART [Lamivudine $(300 \mathrm{mg} /$ day), Stavudine $(60 \mathrm{mg} /$ day $)$ and Nevirapine $(400 \mathrm{mg} /$ day)]. Twentynine subjects had not received any antiretroviral therapy as at the time of enrolment. Six subjects who exhibited clear evidence of acquired immune deficiency syndrome (AIDS) were also included. Twelve healthy HIV-1 sero-negative volunteers were recruited within the vicinity of the centre for this study. Volunteers with additional conditions that could affect evaluated parameters, such as pregnancy and tuberculosis infection were excluded from the study. Informed consent was obtained from all volunteers before initiation of the study. The LIHOC Ethical Committee of approved the study.

\section{Specimens collection and preservation}

Blood sampling was done by venipuncture and transported under ice-cold condition to the laboratory within six hours. Serum was separated from whole blood by centrifugation at $1000 \mathrm{x}$ g for ten minutes and stored in aliquots at $-200 \mathrm{C}$ until analyzed.

\section{Diagnosis of HIV infection and CD4 T-cell cytometry}

The diagnosis of HIV-1 infection was performed by enzyme link immunosorbence assay (ELISA) and confirmed by HIV Western Blot using ImmuneticsQualicode HIV-1/2 Kit (USA). Subjects with indeterminate results were excluded from the study. Control subjects were also confirmed to be negative for antibodies to HIV.EDTAanticougulated blood CD4T-cell was enumerated using Cyflow ${ }^{\circledR}$ Cytometer according to the manufacturer's instructions (Partec, Germany). 


\section{Alpha I antitrypsin ( $\alpha$ I AT) assay}

The serum concentration of $\alpha 1 \mathrm{AT}$ of subjects was determined using a commercial radial immunodifussion assay plates purchased from Liofilchemsrl, Italy. The procedure was carried out according to manufacturer's instructions.

\section{Statistical analysis}

Descriptive analysis, and student t-test and Spearman correlation were respectively, employed to compare data and test association between variables using Graph Pad 5 software (San Diego, CA). P-values $<0.05$ were considered significant.

\section{Results}

\section{Characteristics of study subjects}

HIV-1 infected subjects naïve to HAART had a median CD4 lymphocyte count of 440 (IQR 321-510) cells $/ \mu 1$ while that of HIV1 infected subjects under HAART was 410 (IQR 300-605) cells/ $\mu 1$. Although, the male to female ratio was approximately 0.3 , the blood CD4 T-cell counts of the groups were not significantly different $(\mathrm{p}=0.527)$. The detailed characteristics of the subjects are shown in Table 1.

Table I Characteristics of study subjects

\begin{tabular}{llllll}
\hline Characteristics & HIV- & HAART- & HAART+ & HAART+/AIDS & p-Value* \\
\hline N & 12 & 29 & 33 & 6 & \\
Age $($ year $)$ & $37(35,45)$ & $35(34,49)$ & $35(32,47)$ & $42(31,6 I)$ & $0.27 \mathrm{I}$ \\
MAC $(\mathrm{cm})$ & $28(24,29)$ & $28(26,30)$ & $27(27,3 \mathrm{I})$ & $20(19,24)$ & 0.6 \\
Sex $(\mathrm{M} / \mathrm{F})$ & 02-Jan & $22-\mathrm{Jul}$ & $26-\mathrm{Jul}$ & $03-\mathrm{Jan}$ & 0.405 \\
$\mathrm{ID}($ month) & NA & $12(4,44)$ & $16(10,55)$ & $13(7,19)$ & 0.236 \\
HD (month) & NA & 0 & $14(5,48)$ & $13(7,19)$ & NA \\
CD4 count $(/ \mu \mathrm{l})$ & $734(634,825)$ & $44 \mathrm{I}(319,5 \mathrm{II})$ & $410(300,600)$ & $230(165,295)$ & 0.527 \\
\hline
\end{tabular}

Values are medium ( $25^{\text {th }}$ and $75^{\text {th }}$ percentile). $\mathrm{p}$-values were determined by Student's ' $\mathrm{t}$ ' test and Fisher's exact test, as appropriate to compare HAART- and HAART+, $\mathrm{p}<0.05$ was considered significantly different. NA, not applicable; MAC, mid arm circumference; ID, infection duration; HD, HAART duration

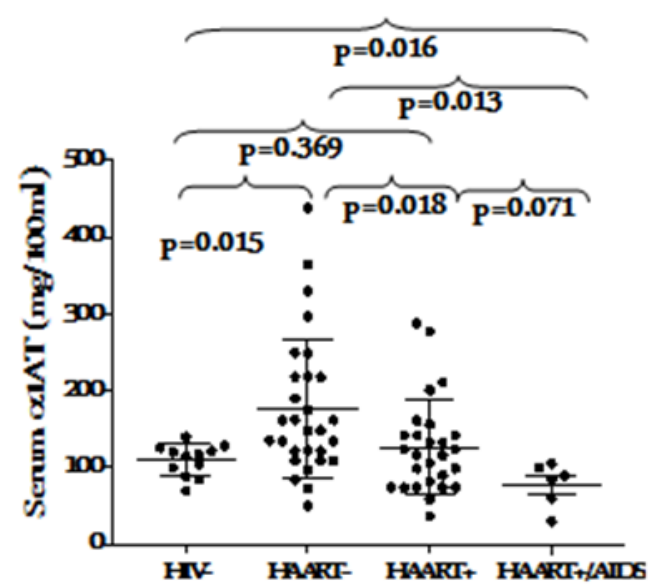

Figure I Serum alpha-I antitrypsin concentration under effective control of HIV disease progression. The dots and error bar represent individual measurements and mean with SD, respectively. P-values were determined by Student's $t$ test and are shown for comparison. $p<0.05$ were considered significantly different.

\section{Serum alpha-I-antitrypsin ( $\alpha$ IAT) concentration under HIV-I disease non-progression}

The concentration of $\alpha 1 \mathrm{AT}$ in the serum of HIV-1 infected subjects under HAART (HAART + ) was compared with those naïve to HAART (HAART-). The HAART- group had a significantly elevated serum concentration of $\alpha 1$ AT than the HAART + and HIV-1 uninfected control group $(\mathrm{p}=0.018$ and $\mathrm{p}=0.015$, respectively Figure 1 . Serum $\alpha 1 \mathrm{AT}$ concentrations $<100 \mathrm{mg} / 100 \mathrm{~mL}$ were found in $14 \%$ and $41 \%$ in HAART- and HAART+ group, respectively. Under effective HAART + , subjects with CD4 + T cell counts $>500$ cells $/ \mu 1$ had similar serum concentration of $\alpha 1 \mathrm{AT}$ with those having CD4+T cell counts $<500$ cells $/ \mu 1$ ( $\mathrm{p}=0.696)$. However, the HAART- group with better CD4 $+\mathrm{T}$ cell counts had higher concentration of $\alpha 1 \mathrm{AT}$, although this was not significant $(\mathrm{p}=0.142)$ Figure 2 . Treatment duration did not have significant effect on the expression of $\alpha 1$ ATin the serum $(\mathrm{p}=0.442)$ Figure 3 .

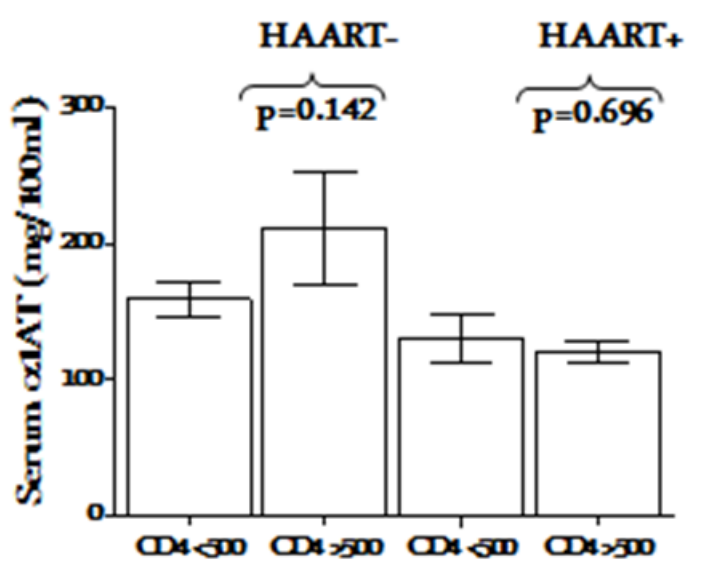

Figure 2 Impact of HIV clinical status on serum alpha-I antitrypsin concentration under effective control of HIV-I disease progression. The bar and error bar represent mean \pm SEM. p-values were determined by Student's $t$ test and are shown for comparison. $\mathrm{p}<0.05$ were considered significantly different.

\section{Association between serum alpha- I antitrypsin ( $\alpha$ | AT) and marker of HIV disease status}

The concentrations of individual serum $\alpha 1$ ATin subjects infected with HIV-1 in both HAART+ and HAART- groups in relation to their blood CD4 counts were correlated. A significant positive correlation was found between serum $\alpha 1 \mathrm{AT}$ and blood CD4+ T cells count in the HAART naïve group $(\mathrm{R}=0.426 ; \mathrm{p}=0.021)$ and no significant correlation was observed in the subjects under HAART $(\mathrm{R}=-0.136$; $\mathrm{p}=0.500$ ) Figure 4.

\section{Discussion}

Alpha-1-antitrypsin ( $\alpha 1 \mathrm{AT})$ has been identified as the most abundant endogenous protease inhibitor, also found to inhibit human 
immunodeficiency virus (HIV) replication. ${ }^{3,12-14}$ We hypothesized that HIV-1 infected subjects that resist progression without treatment (HAART-) wound exhibit a higher serum levels of $\alpha 1$ AT than in subjects in whom control of disease progression was achieved by HAART. It was first investigated whether increased serum concentration of $\alpha 1 \mathrm{AT}$ would is associated with effective control of HIV-1 infection in the absence of HAART and then whether serum $\alpha 1 \mathrm{AT}$ concentrations were associated with clinical (CD4 counts) status.

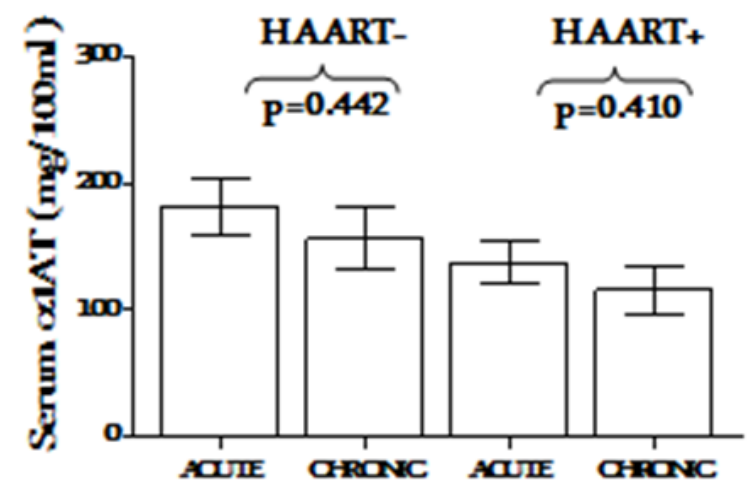

Figure 3 Impact of HAART/infection durations on serum alpha-I antitrypsin concentration under effective control of HIV-I disease progression. The bar and error bar represent mean \pm SEM. $p$-values were determined by Student's $t$ test and are shown for comparison. $\mathrm{p}<0.05$ were considered significantly different.

HAART -

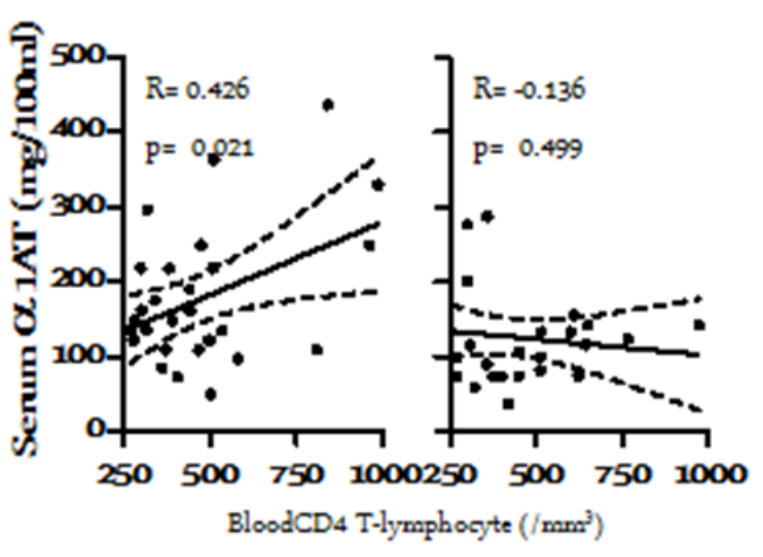

Figure 4 Association between serum alpha-I antitrypsin ( $\alpha$ IAT) and marker of HIV disease status (blood CD4 counts) under effective control of HIV-I disease progression. Each dot represents an individual subject's $\alpha$ IAT concentration. Regression lines and Pearson R-values are shown for correlations. The dotted lines are $95 \%$ confidence band. $p$-value $<0.05$ were considered significant.

It was discovered that the serum concentration of $\alpha 1 \mathrm{AT}$ was higher in HIV-1 infection under effective control of disease progression than in HIV-1 uninfected subjects. This is not in complete agreement with Bryan et al. ${ }^{10}$ who reported that HIV infection was associated with reduced concentration of $\alpha 1 \mathrm{AT}$ compared with HIV-1 uninfected control In our present study, only a cohort of HIV-1-infected subjects with evidence of AIDS exhibited reduced concentration of a1AT compared with HIV-1 uninfected control $(\mathrm{p}=0.016)$. The discrepancies might be attributed to the fact that the majority of HIV-1 infected in
Bryan et al. ${ }^{10}$ study met the 1993 CDC criteria for AIDS ${ }^{15}$ while only six subjects in our present study met the AIDS criteria. Evidently, HIV disease progression was well controlled in our subjects; either by host immunological responses (HAART-) or by ARV (HAART+). It is also interesting to note that, compared with HIV-uninfected control, significantly $(p=0.013)$ low levels $\alpha 1$ AT was found in subjects with evidence of AIDS in our study. We are not certain whether the subjects that resist progression to AIDS in the absence of treatment constitutively expressed elevated $\alpha 1 \mathrm{AT}$ prior to infection or the increased expression was a natural response to HIV infection in the cohorts. In a previous study, Adedeji et al. ${ }^{16}$ showed that this group of subject possessed and retained the ability to synthesized immunoglobulin. It is also possible that the cohort possessed the natural ability to respond to HIV infection by synthesizing a1AT and of course, increased expression $\alpha 1 \mathrm{AT}$ would contribute to nonprogression in the absence of treatment. Normal $\alpha 1$ AT phenotype may also be associated with the ability of host to express the protein as abnormal $\alpha 1$ AT phenotype has been demonstrated to be associated with HIV disease progression ${ }^{2}$ and HIV infection in a patient with alpha-1 antitrypsin deficiency has been described as a detrimental combination. ${ }^{17}$ However, Ferreira et al., ${ }^{18}$ suggested that deficiency in $\alpha 1$ AT may be a risk factor for acquisition of HIV infection, but physiological $\alpha 1 \mathrm{AT}$ concentrations do not affect disease progression after infection occurs.

Based on treatment status, HIV-1 infected subjects that resist progression without treatment (HAART-) exhibited a significantly $(\mathrm{p}=0.018)$ higher serum levels of $\alpha 1 \mathrm{AT}$ compared to subjects in whom control of disease progression was achieved by HAART $(\mathrm{HAART}+) . \alpha 1 \mathrm{AT}$ is an acute phase protein with HIV-1 inhibitory properties $^{13}$ and tissues inhibitor of serine proteinase implicated in the regulation of inflammation and host defense, ${ }^{19,20}$ the elevated a1AT may be associated with control of HIV replication and thus disease progression in the absence of HAART. Although Bryan et al. ${ }^{10}$ reported no association between serum $\alpha 1 \mathrm{AT}$ levels and viral load or use of antiretroviral therapy in HIV-infected subjects; we were unable to determine the viral load to compare the extent of viral replication control more importantly in the HAART-naïve group with elevated serum $\alpha 1 \mathrm{AT}$ concentration. Further studies will focus on the association between of elevated serum $\alpha 1 \mathrm{AT}$ concentration and viral load in HIV-infected subject who resist progression in the absence of HAART.

Stratification based on HIV clinical status and HAART/infection duration added another dimensions to the present study. We compared the $\alpha 1 \mathrm{AT}$ concentration in groups defined by the blood CD4 count (CD4 $<500$ or $>500 / \mu 1)$. While no apparent difference was observed in the in HIV-1-infected subjects under HAART $(\mathrm{p}=0.696)$, subjects with better clinical status exhibited a higher (although not statistically significant $\mathrm{p}=0.142$ ) $\alpha 1 \mathrm{AT}$ under HAART Figure 2 . This indicates the possible association of elevated $\alpha 1 \mathrm{AT}$ concentration with clinical status. Bryan et al. ${ }^{10}$ found no association between very low $\alpha 1 \mathrm{AT}$ concentrations and clinical status. It is interesting that we found a significant positive correlation $(\mathrm{R}=0.426 ; \mathrm{p}=0.021)$ of $\alpha 1 \mathrm{AT}$ with marker of disease status in subject who resisted progression in the absence of HAART Figure 4. We similarly compared serum $\alpha 1$ AT concentration in groups defined by infection and HAART duration (Acute or chronic). In this study, we employ our earlier criteria ${ }^{16}$ to classify the subjects. Although, increased better outcomes had been associated with longer HAART duration, especially in preventing mother to child transmission, ${ }^{21}$ serum $\alpha 1$ AT was not associated with HAART duration in the present study Figure 3. 
Summarily, we have shown that host ability to exhibit increased expression of $\alpha 1 \mathrm{AT}$ is associated with HIV-disease non-progression in the absence of HAART. Our findings support the possible use of alpha-1-antitrypsin in HIV disease management.

\section{Conclusion}

We conclude that significantly higher serum $\alpha 1$ ATconcentration contributes to the effective control of HIV-1 disease progression in the absence of HAART. Determination of $\alpha 1$ AT phenotypes of this subset may provide more insight into this phenomenon.

\section{References}

1. Janciauskiene SM, Bals R, Koczulla R, et al. The discovery of a1antitrypsin and its role in health and disease. Respiratory Medicine. 2010;105(8): 1129-1139.

2. Donato LJ, Jenkins SM, Smith C, et al. Reference and interpretive ranges for $\alpha$-1-antitrypsin quantitation by phenotype in adult and pediatric populations. American Journal of Clinical Pathology. 2012;138(3):398405 .

3. Blank CA, Brantly M. Clinical features and molecular characteristics of a-1-antitrypsin deficiency. Annals of Allergy. 1994;72(2):105-120.

4. Oakeshott JG, Muir A, Clark P, et al. Effects of the protease inhibitor (Pi) polymorphism on alpha-1-antitrypsin concentration and elastase inhibitory capacity in human serum. Annals of Human Biology. 1985;12(2):149-160.

5. Travis J, Owen M, George P, et al. Isolation and properties of recombinan DNA produced variants of human alpha1-proteinase inhibitor. Journal of Biological Chemistry. 1985;260(7):4384-4389.

6. Kolarich D, Altmann F, Sunderasan E. Structural analysis of the glycoprotein allergen $\mathrm{Hev}$ b 4 from natural rubber latex by mass spectrometry. Biochimica Biophysica Acta. 2006;1760(4):715-720.

7. Knappstein S, Ide T, Schmidt MA, et al. Alpha-1-antitrypsin binds to and interferes with functionality of EspB from atypical and typical enteropathogenic Escherichia coli strains. Infection and Immunology. 2004;72(8):4344-4350.

8. Bilello JA, Bilello PA, Stellrecht K, et al. Human serum alpha-1 acid glycoprotein reduces uptake, intracellular concentration, and antiviral activity of A-80987, an inhibitor of the human immunodeficiency virus type 1 protease. Antimicrobial Agents and Chemotherapy. 1996;40(6):1491-1497.

9. Münch J, Ständker L, Adermann K, et al. Discovery and optimization of a natural HIV-1 entry inhibitor targeting the gp41 fusion peptide. Cell. 2007;129(2):263-275.
10. Bryan CL, Beard KS, Pott GB, et al. HIV infection is associated with reduced serum alpha-1-antitrypsin concentrations. Clinical Investigative Medicine. 2010;33(6):E384-E389.

11. Zhou X, Shapiro L, Fellingham G, et al. HIV replication in CD4+ T lymphocytes in the presence and absence of follicular dendritic cells: inhibition of replication mediated by $\alpha$-1-antitrypsin through altered I $\mathrm{kBa}$ ubiquitination. Journal of Immunology. 2011;186(5):3148-3155.

12. Massi G, Chiarelli C. Alpha-1-antitrypsin: molecular structure and the Pi system. Acta Paediatica Supplement. 1994;393:1-4.

13. Shapiro L, Pott GB, Ralston AH. Alpha-1-antitrypsin inhibits human immunodeficiency virus type 1. Federation of American Society for Experimental Biology Journal. 2001;15(1):115-122.

14. Elmaleh DR, Brown NV, Geiben-Lynn R. Anti-viral activity of human antithrombin III. International Journal of Molecular Medicine. 2005;16(2):191-200.

15. Centre for disease control and prevention (CDC). 1993 revised classification system for HIV infection and expanded surveillance case definition for AIDS among adolescents and adults. Morbidity and Mortality Weekly Reports. 1992;41(RR-17):1-19.

16. Adedeji AL, Adenikinju RO, Ajele JO, et al. Serum protein electrophoresis under effective control of HIV-1 disease progression. Experimental and Clinical Science International Journal. 2014;13:761771

17. Potthoff AV, Münch J, Kirchhoff F, et al HIV infection in a patient with alpha-1 antitrypsin deficiency: a detrimental combination? AIDS. 2007;21(15):2115-2116

18. Ferreira TC, Sampaio EP, Argañaraz GA, et al. Increased prevalence of the alpha-1-antitrypsin (A1AT) deficiency-related S gene in patients infected with human immunodeficiency virus type 1. Journal of Medical Virology. 2014;86(1):23-29.

19. Bucurenci N, Blake DR, Chidwick K, et al. Inhibition of neutrophil superoxide production by human plasma alpha-1-antitrypsin. Federation of European Biochemical Societies Letters. 1992;300(1):21-24.

20. Hadzic R, Nita I, Tassidis H, et al. Alpha-1-antitrypsin inhibits Moraxella catarrhalis MID protein-induced tonsillar B cell proliferation and IL-6 release. Immunology Letters. 2006;102(2):141-147.

21. Hoffman RM, Black V, Technau K, et al. Effects of highly active antiretroviral therapy duration and regimen on risk for mother-to-child transmission of HIV in Johannesburg, South Africa. Journal of Acquired Immune Deficiency Syndrome. 2010;54(1):35-41. 